\title{
PEMANFAATAN TEKNOLOGI LOCATION BASE SERVICE UNTUK SISTEM MONITORING TENAGA KERJA INDONESIA DI LUAR NEGERI
}

\author{
Slamet Risnanto ${ }^{1)}$, Hanhan Hanafiah Solihin ${ }^{2)}$ \\ Program Studi Teknik Informatika ${ }^{1)}$, Program Studi Sistem Informasi ${ }^{2)}$ \\ Universitas Sangga Buana YPKP ${ }^{1) 2}$ \\ Slamet.risnanto@usbypkp.ac.id ${ }^{1)}$, Hanhan.hanafiah@usbypkp.ac.id ${ }^{2)}$
}

\begin{abstract}
ABSTRAK
Menurut Badan Nasional Perlindungan dan Penempatan Tenaga Kerja Indonesia (BNP2TKI), Jumlah kiriman uang TKI di luar negeri pada tahun 2014 mencapai 105.9 trilyun tidak salah apabila dikatakan bahwa TKI adalah pahlawan devisa, Terlepas dari relatif banyaknya devisa yang masuk ke Indonesia dari TKI, banyaknya masalah yang dihadapi TKI di Negara tujuan menjadi problem tersendiri khususnya bagi BNP2TKI, Depnaker dan Departemen Luar Negeri, tercatat pada tahun 2014 BNP2TKI menerima 2963 laporan masalah, umumnya masalah-masalah yang terjadi diantaranya TKI sudah selesai kontrak namun belum pulang ke tanah air, gaji tidak dibayar, meninggal di negara penempatan, putus hubungan komunikasi, pekerjaan tidak sesuai perjanjian kerja, TKI sakit yang perlu di rawat inap, TKI gagal berangkat, penganiayaan, kecelakaan, tidak berdokumen, lari dari majikan, dan TKI ditahan, Kegagalan dan telatnya perlindungan terhadap TKI umumnya karena komunikas dan koordinasi yang sulit dibangun sehingga membutuhkan adopsi teknologi yang bisa setiap saat

Teknologi Location Base Service adalah teknologi yang dilayani oleh google merupakan teknologi yang banyak diadopsi oleh aplikasi-aplikasi berbasiskan GIS yang ada di Indonesia dan mancanegar, Pemanfaatan teknologi Location Base Service untuk monitoring TKI di luar negeri akan sangat membantu stake holder yang terkait untuk memonitor dan koordinasi TKI yang jumlahnya relatif banyak sehingga bisa miminimalisir masalah-masalah yang timbul terhadap TKI di luar negeri
\end{abstract}

Kata kunci : Tenaga Kerja Indonesia, Location base Service, BNP2TKI

\section{Pendahuluan}

Teknologi LBS (Location Based Service) ${ }^{[1]}$ merupakan layanan informasi yang memanfaatkan kemampuan penunjuk lokasi pada piranti bergerak dan dapat diakses melalui jaringan mobile". LBS (Location Based Service) merupakan salah satu bagian dari implementasi Sistem Informasi Geografis (SIG) yang lebih cenderung memberikan terapan sehari-hari seperti menampilan direktori kota, navigasi kendaraan dan pencarian alamat. Menurut sumber ${ }^{[2]}$ sistem informasi geografis adalah sistem informasi khusus yang mengelola data yang memiliki informasi spasial (bereferensi keruangan).
Secara garis besar monitoring Tenaga Kerja Indonesia di luar negeri yang selanjutnya disebut TKI diperlukan untuk perlindungan dan bahan evaluasi Departemen Tenaga Kerja, Badan Nasional Perlindungan dan Penempatan Tenaga kerja Indonesia disingkat BNP2TKI dan kedutaan besar dinegara dimana Tenaga Kerja Indonesia tersebut bekerja.

Sistem yang akan dihasilkan dalam penelitian ini adalah Aplikasi monitoring Tenaga Kerja Indonesia dengan memanfaatkan teknologi Location Base Service yang akan memberikan informasi berupa peta dan koordinat posisi Tenaga Kerja Indonesia yang bisa dipakai oleh Departemen Tenaga Kerja,BNP2TKI dan 
kedutaan besar sehingga masalah-masalah yang sering muncul seperti TKI pindah karena pindah domisili, hilang kontak, mendapatkan perlakuan tidak baik dan lain lain bisa diminimalisir oleh sistem ini.

\subsection{Permasalahan}

Permasalahan yang diangkat dalam penulisan penelitian ini adalah bagaimana membangun sistem monitoring keberadaan dan posisi TKI di luar negeri menggunakan teknologi Location base Service yang akan membantu Departemen tenaga kerja, Badan Nasional Perlindungan dan Penempatan Tenaga kerja Indonesia (BNP2TKI) dan kedutaan besar.

Menurut Sub Dinas pengolahan dan Penyajian data BNP2TKI [3], pada tahun 2014 tercatat 429.872 TKI bekerja di luar negeri dan dalam tahun yang sama, BNP2TKI menerima $2963^{\text {[4] }}$ laporan masalah, umumnya masalahmasalah yang terjadi diantaranya TKI sudah selesai kontrak namun belum pulang ke tanah air, gaji tidak dibayar, meninggal di negara penempatan, putus hubungan komunikasi, pekerjaan tidak sesuai perjanjian kerja, TKI sakit yang perlu di rawat inap, TKI gagal berangkat, penganiayaan, kecelakaan, tidak berdokumen, lari dari majikan, dan TKI ditahan.

Kegagalan dan telatnya perlindungan terhadap TKI umumnya karena komunikas dan koordinasi yang sulit dibangun sehingga membutuhkan adopsi teknologi yang bisa setiap saat memonitor keberadaan TKI di luar negeri,

\subsection{Tujuan Penelitian}

Secara umum tujuan penelitian ini adalah

1. Pemanfaatan teknologi yang ada untuk memudahkan para stake holder Tenaga Kerja Indonesia memonitor keberadaan dan posisi TKI secara real time

2. Meminimalisir dan tindakan preventif terhadap masalah masalah yang muncul pada TKI di luar negeri.
3. Meningkatkan koordinasi antara tenaga kerja Indonesia, Departemen tenaga kerja, Badan Nasional Perlindungan dan Penempatan TKI (BNP2TKI) dan kedutaan besar

\section{Tinjauan Pustaka}

\subsection{Location Base Service}

Menurut sumber ${ }^{[2]}$ teknologi Location Based Service (LBS) merupakan salah satu bagian implementasi dari mobile GIS (Graphipcal Information System) yang lebih cenderung memberikan fungsi terapan seharihari menampilkan direktori kota, navigasi kendaraan, pencarian alamat serta jejaring sosial dibandingkan fungsionalitas pada GIS. Location Based Service (LBS) merupakan layanan informasi yang memanfaatkan kemampuan penunjuk lokasi pada piranti bergerak dan dapat diakses melalui jaringan mobile yang dilengkapi dengan kemampuan untuk memanfaatkan lokasi dari perangkat mobile tersebut. Dua unsur utama LBS adalah :

1. Location Manager(API Maps) Menyediakan tools/source untuk LBS, Application Programming Interface (API) Maps menyediakan fasilitas untuk menampilkan, memanipulasi peta beserta fitur lainnya seperti satelit, jalan maupun gabungannya.

1. Locations Provider(API Location) Menyediakan teknologi pencarian lokasi yang digunakan oleh perangkat. API Location bergubungan dengan data GPS (Global Positioning System) dan data lokasi secara real time. Dengan location manager dapat ditentukan lokasi pengguna dan juga rute menuju tempat tertentu.

Elemen yang diperlukan untuk menggunakan layanan berbasis lokasi menurut Safaat (2012:178) adalah :

1. Mobile devices yaitu sebuah alat yang digunakan untuk meminta informasi yang dibutuhkan. Perangkat yang memungkinkan yaitu PDA, mobile phones, laptop, dan perangkat lainnya yang mempunyai fasilitas navigasi. 
2. Communication network adalah jaringan selular yang mengirimkan data pengguna dan permintaan layanan.

3. Positioning component untuk pengolahan layanan biasanya posisi pengguna harus ditentukan. Posisi pengguna dapat diperoleh menggunakan Global Positioning System (GPS).

4. Service and application provider adalah penyedia layanan pengguna selular yang bertanggung jawab untuk memproses layanan.

5. e. Data and content provider yaitu penyedia layanan informasi data yang dapat diminta oleh pengguna.

\subsection{Monitor}

Dalam kamus bahasa Indonesia ${ }^{[5]}$ Monitor adalah memantau dan cek secara cermat sedangkan memonitor adalah mengawasi, mengamati, atau mengecek dng cermat, terutama untuk tujuan khusus

\subsection{Tenaga Kerja Indonesia}

Menurut Undang-Undang Nomor 39 Tahun 2004 Pasal 1 ayat 1 [6] Tentang Penempatan dan Perlindungan Tenaga Kerja Indonesia di Luar Negeri ("UU No.39/2004") disebutkan bahwa: "Tenaga Kerja Indonesia yang selanjutnya disebut dengan TKI adalah setiap warga negara Indonesia yang memenuhi syarat untuk bekerja di luar negeri dalam hubungan kerja untuk jangka waktu tertentu dengan menerima upah ", Berdasarkan undangundang atas, dapat diketahui bahwa TKI merupakan tenaga kerja Indonesia yang berada di luar negeri atau ditempatkan di luar negeri untuk suatu pekerjaan.

\section{4. . UML (Unified Modeling Language)}

Peralatan pendukung yang digunakan penulis dalam merancang aplikasi adalah UML (Unifield Modeling Language). sebagai bahasa, berarti UML memiliki sintaks dan semantik. Ketika membuat model menggunakan konsep UML ada aturan-aturan yang harus diikuti.
Bagaimana elemen-elemen pada model yang dibuat berhubungan satu dengan lainnya harus mengikuti standar yang ada, UML diaplikasikan untuk maksud tertentu, biasanya antara lain untuk :

1. Merancang perangkat lunak.

2. Sarana komunikasi antara perangkat lunak dengan proses bisnis.

3. Menjabarkan sistem secara rinci untuk analisa dan mencari apa yang diperlukan sistem.

4. Mendokumentasikan sistem yang ada, proses-proses dan organisasinya.

Blok pembangun utama UML adalah diagram. Beberapa diagram ada yang rinci (jenis timing diagram) dan lainnya ada yang bersifat umum (misalnya diagram kelas). Para pengembang sistem berorientasi objek menggunakan bahasa model untuk menggambarkan, membangun, dan mendokumentasikan sistem yang dirancang. UML memungkinkan para anggota tim untuk bekerja sama dengan bahasa model yang sama dalam mengaplikasikan beragam sistem. Intinya, UML merupakan alatkomunikasi yang konsisten dalam mendukung para pengembang sistem saat ini. Sebagai perancang sistem, mau tidak mau pasti akan menjumpai UML. UML telah diaplikasikan dalam bidang investasi, perbankan, lembaga kesehatan, departemen pertahanan, sistem terdistribusi dan lain-lain ${ }^{[7]}$

\section{PEMBAHASAN}

\subsection{Analisis Kebutuhan}

Analisis kebutuhan dititik beratkan pada masalah-masalah yang diuraikan diatas, beberapa kebutuhan sistem yang sangat mendesak adalah :

1. Sistem yang bisa memonitor keberadaan dan lokasi TKI secara real time

2. Sistem yang bisa memonitor pergerakan atau perpindahan tempat TKI secara real time

3. Sistem yang bisa mengetahui kondisi keadaan darurat TKI secara real time

\subsection{Adopsi Teknologi}

JURNAL INFOTRONIK 96 
Stake holder pada sistem ini adalah dinas tenaga kerja, BNP2TKI, Kedutaan Besar negaranegara tujuan Tenaga Kerja Indonesia, Departemen Luar Negeri dan Tenaga Kerja Indonesia, Gambar berikut ini menunjukan rancangan adopsi teknologi Location Base Service untuk monitoring TKI diluar negeri dimana sistem yang dibangun melibatkan 2 sisi yaitu sisi alat monitoring dan alat yang melekat di TKI sedangkan pemetaan lokasi memanfaatkan Google Map server

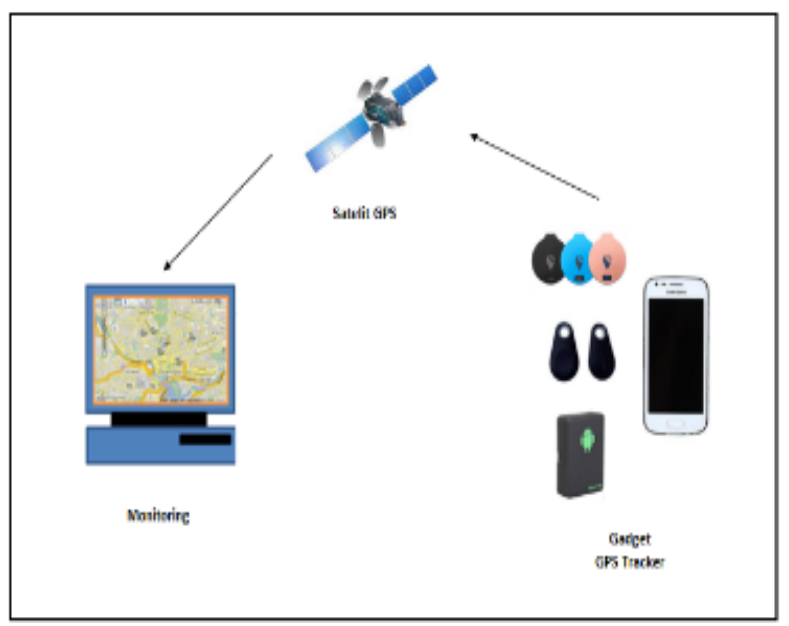

Gambar 1 : Rancangan adopsi teknologi LBS

\subsection{Perancangan}

\section{Use Case diagram}

Diagram Use Case adalah gambaran fungsionalitas yang diharapkan dari sebuah sistem, dibawah ini diagram use case sebagai gambaran fungsi yang diharapkan dari sistem monitoring TKI yang diharapkan

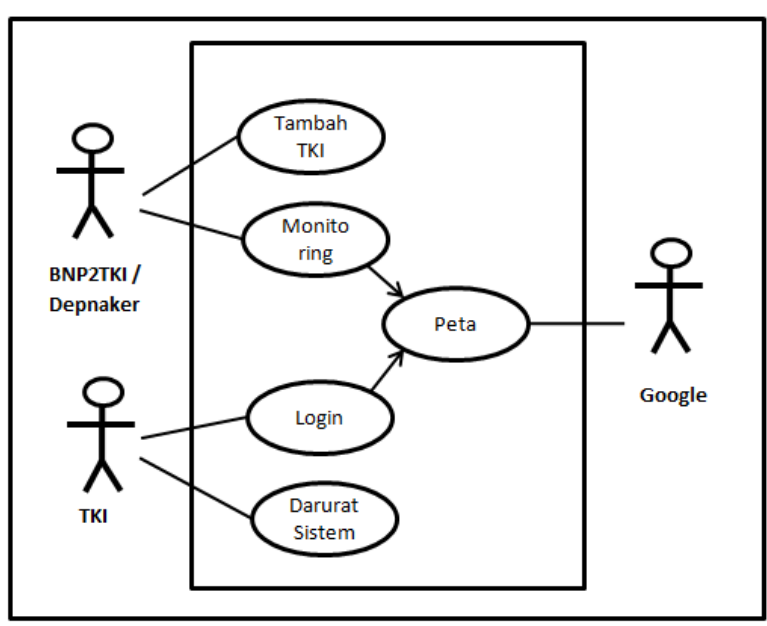

Gambar 2 : Use case diagram

Pada gambar 2 diatas, terdapat 3 aktor yang terlibat dalam sistem tersebut yaitu

1. BNP2TKI / Depnaker merupakan pemilik sistem dimana berfungsi untuk menambah TKI yang akan bekerja diluar negeri dan mendapatkan informasi monitoring lokasi dan keadaan TKI tersebut

2. Tenaga Kerja Indonesia / TKI merupakan sumber informasi untuk bertugas melakukan login dan automatis lokasi TKI tersebut terlacak dalam sistem, TKI juga akan mendapatkan tombol panic berfungsi apabila TKI mendapatkan perlakuan atau situasi yang tidak lazim.

3. Google, merupakan penyedia peta dunia untuk memberikan informasi pemetaan posisi TKI

\section{Prototype Graphic User Interface (GUI)}




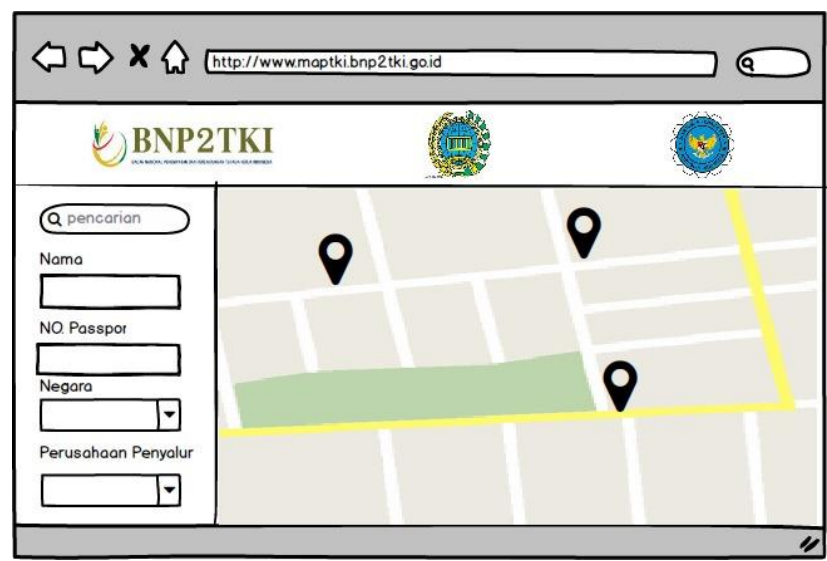

Gambar 3 : Rancangan tampilan utama monitoring TKI

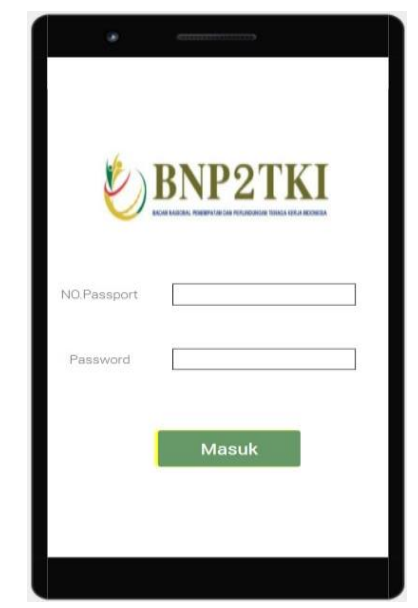

Gambar 4 : Rancangan tampilan utama di alat / Gadget TKI

\section{PENUTUP}

\subsection{Kesimpulan}

1. Teknologi Location Base Service adalah teknologi yang dilayani oleh google adalah teknologi yang banyak diadopsi oleh aplikasi-aplikasi berbasiskan GIS yang ada di Indonesia dan mancanegara

2. Pemanfaatan teknologi Location Base Service untuk monitoring TKI di luar negeri akan sangat membantu stake holder yang terkait untuk memonitor dan koordinasi TKI yang jumlahnya relative banyak
3. Pada implementasinya, pasti akan ada kendala terutama di sisi aplikasi yang diterapkan di sisi TKI terutama para TKI yang kebetulan mendapatkan majikan yang over protektif

\subsection{Saran}

1. Dari kesimpulan yang didapat, disarankan BNP2TKI atau para stake holder yang berhubungan dengan TKI untuk segera menererapkan teknologi ini untuk menutupi permasalahanpermasalahan yang ada

2. Kendala yang akan banyak didapat adalah di sisi TKI, terutama TKI yang kebetulan mendapatkan majikan yang over protektif, disarankan Alat yang berupa gadget dimodifikasi menjadi alat yang disamarkan sehingga TKI masih tetap bisa termonitor atau terdeteksi keberadaanya.

\subsection{Profile Penulis}

Slamet Risnanto,ST.,M.Kom. Dosen tetap Program Studi Teknik Informatika Universitas Sangga Buana YPKP yang sekaligus menjabat Ketua Program studi tersebut peroide 2015-2019 dan Dosen Luar Biasa di beberapa Perguruan Tinggi di Bandung serta aktif sebagai praktisi Sistem Informasi.

\section{Daftar Pustaka}

[1] Rokhman, Nur, dan Iqnatius Dimas Nugroho. 2013. Aplikasi Pencarian Lokasi Fasilitas Umum Berbasis Foursquare APIv2 pada Sistem Operasi Android. Yogyakarta. Vol. 7, No. 2: 209-220.

[2] Kusuma, Wahyu, Siti Eriza Mulyani, dan Any Yapie. 2013. Aplikasi Location Based Service Taman Mini Indonesia Indah (TMII) Berbasis Android. Yogyakarta : Seminar Nasional Aplikasi Teknologi Informasi 2013. ISSN: 19075022. 
[3] www.bnp2tki.go.id. 2015. Sepanjang 2014 BNP2TKI Mencatat Penempatan TKI 429.872 Orang, diakses 12 Agustus 2014

[4] www.liputan6.com . 2014. BNP2TKI Terima 2.967 Laporan Masalah TKI , diakses 12 Agustus 2015

[5] www.kbbi.web.id , 2015 , Kamus Besar Bahasa Indonesia, diakses 15 Agustus 2015

[6] www.hukumtenagakerja.com , 2015 , Undang Undang Tenaga Kerja , diakses 15 Agustus 2015

[7] Prabowo Pudjo Widodo dan Herlawati. 2011. Menggunakan UML. Bandung : Informatika. 